\title{
EFEKTIVITAS EKSTRAK DAUN TOMAT (Solanum Iycopersicum L.) SEBAGAI OVISIDA NYAMUK Aedes aegypti
}

\author{
Mira Madona ${ }^{1}$, Endah Setyaningrum ${ }^{1}$, Gina Dania Pratami ${ }^{1}$, \\ Mohammad Kanedi ${ }^{1}$
}

\author{
${ }^{1}$ Jurusan Biologi, Fakultas Matematika dan Ilmu Pengetahuan Alam, \\ Universitas Lampung
}

\begin{abstract}
Effectiveness Of Tomato Leaf Extract (Solanum Lycopersicum L.) As A Mosquito Ovisida Aedes aegypti. Aedes aegypti mosquito control as a vector of dengue hemorrhagic fever (DHF) has been carried out using chemical control that will cause resistance to Ae. aegypti so natural insecticide is needed. Solanum fruit (Solanum lycopersicum L.) that contains the active compounds such as flavonoids, saponins, alkaloids and essential oils are entomotoxicity which can inhibit eggs hatchability of Ae. aegypti. Purpose was to determine the effectiveness of Solanum extracts as the ovicides of Ae. aegypti. Design is an experimental research with a completely randomized with 6 treatment groups $0,1 \%, 0,3 \%$, $0,5 \%, 0,7 \%, 1 \%$ and $0 \%$ (control) with 25 eggs in each groups and 4 repetitions. Then, it was observed in 6 hours for 72 hours, and at 18 hours would be performed a test analysis to gain cumulative data of one way ANOVA. The results showed the number of eggs did not hatch had a significant difference $(p=0,000)$. While the post-hoc LSD test results showed that the most effective concentration as ovicides of Ae. aegypti was $1 \%$.
\end{abstract}

Keywords : Aedes aegypti, Solanum lycopersicum, Ovicides.

\begin{abstract}
Abstrak : Efektivitas Ekstrak Daun Tomat (Solanum Lycopersicum L.)
Sebagai Ovisida Nyamuk Aedes Aegypti. Pengendalian nyamuk Aedes aegypti sebagai vektor Demam Berdarah Dengue (DBD) telah banyak dilakukan dengan menggunakan pengendalian kimiawi yang semakin lama akan menimbulkan resistensi terhadap nyamuk $A e$. aegypti sehingga dibutuhkan insektisida alami. Daun tomat (Solanum lycopersicum L.) memiliki kandungan flavonoid, saponin, alkaloid dan minyak atsiri bersifat entomotoxicity yang dapat menghambat daya tetas telur nyamuk Ae. aegypti. Tujuan penelitian ini adalah mengetahui efektivitas ekstrak daun tomat sebagai ovisida nyamuk Ae. aegypti. Desain penelitian ini adalah eksperimental menggunakan Rancangan Acak Lengkap (RAL) dengan 6 kelompok perlakuan yaitu $0,1 \% ; 0,3 \% ; 0,5 \% ; 0,7 \% ; 1 \%$ dan $0 \%$ (kontrol) dengan 25 butir telur pada tiap kelompok dan 4 pengulangan pada tiap perlakuan. Jumlah telur yang tidak menetas diamati setiap 6 jam sekali selama 72 jam, data kumulatif pada jam ke 18 dilakukan uji analisis one way ANOVA. Hasil penelitian ini menunjukkan bahwa jumlah telur yang tidak menetas antar perlakuan ada perbedaan secara bermakna $(p=0,000)$ sedangkan hasil uji Post-hoc LSD menunjukkan bahwa konsentrasi yang paling efektif sebagai ovisida nyamuk $A e$. aegypti adalah konsentrasi $1 \%$.
\end{abstract}

Kata Kunci : Aedes aegypti, Daun Tomat, Ovisida.

\section{PENDAHULUAN}

Indonesia merupakan negara yang mempunyai keragaman spesies hewan salah satunya serangga. Serangga mempunyai banyak manfaat bagi manusia. Meskipun demikian, tidak sedikit serangga yang membawa kerugian bagi manusia. Salah satu serangga yang menjadi vektor penyakit adalah nyamuk (Sukohar, 2014). 
Nyamuk Ae. aegypti merupakan vektor utama virus dengue yang menyebabkan penyakit Demam Berdarah Dengue (DBD) (Anushka dkk, 2017).

Pengendalian vektor DBD terutama dilakukan dengan memanfatkan insektisida kimiawi. Masyarakat menganggap metode ini lebih mudah dilakukan karena bersifat lebih instan dan murah, tetapi dapat menimbulkan pencemaran lingkungan dan resistensi terhadap nyamuk karena residunya tidak dapat diuraikan dan dapat memasuki rantai makanan (Subashini dkk, 2017). Berdasarkan hal tersebut dibutuhkan penanganan yang mampu mencegah dan memberantas keberadaan nyamuk Ae. aegypti menggunakan bahan alami, ramah lingkungan dengan residu yang pendek sehingga tidak menimbulkan efek samping yang berbahaya bagi manusia dan mencegah terjadinya resistensi terhadap nyamuk. Pemakaian insektisida nabati dapat dijadikan sebagai suatu sistem alternatif dalam mengatasi penyebaran vektor nyamuk Ae. aegypti (Campbell, 2008).

Tanaman yang mengandung senyawa flavonoid, alkaloid, terpenoid, saponin, tanin, dan minyak atsiri adalah tanaman yang memiliki kemampuan untuk menghambat bahkan merusak membran telur (Raveen dkk, 2017). Tanaman tomat merupakan tanaman yang mengandung senyawa metabolit sekunder seperti flavonoid, alkaloid, saponin dan minyak atsiri sehingga dalam penelitian ini digunakan tanaman tomat sebagai ovisida terhadap telur nyamuk Ae.aegypti.

\section{METODE}

Penelitian ini menggunakan metode eksperimental dengan Rancangan Acak Lengkap menggunakan 25 butir telur Aedes aegypti dengan 6 konsentrasi dan 4 kali pengulangan (WHO, 2005; Bria dkk, 2008). Bahan yang digunakan dalam penelitian ini terdiri dari daun tomat (Solanum lycopersicum L.), telur nyamuk Ae.aegypti yang diperoleh dari
Fakultas Kedoteran Hewan, Institut Pertanian Bogor, Jawa Barat. akuades, dan larutan ethanol $96 \%$.
Daun
tomat
(Solanum.

lycopersicum L.) didapatkan dari daerah Liwa, Lampung Barat sebanyak $3,5 \mathrm{~kg}$ dalam keadaan basah kemudian dicuci dan ditiriskan, lalu dikering anginkan. Setelah kering, daun tomat ditimbang dan dihaluskan dengan menggunakan blender untuk dijadikan serbuk (simplisia). Simplisia sebanyak $500 \mathrm{~g}$ di masukan kedalam beaker glass dan direndam menggunakan larutan ethanol $96 \%$ sebanyak 10 liter selama 3 x 24 jam (Mitarlis dkk, 2011). Setelah dimaserasi larutan tersebut disaring untuk diambil filtratnya dan dilakukan evaporasi atau penguapan pada suhu $40^{\circ} \mathrm{C}$ hingga dihasilkan ekstrak pekat daun tomat (S. lycopersicum L.) $100 \%$ dalam bentuk pasta.

Uji efektivitas ekstrak daun tomat sebagai ovisida pada tahap telur nyamuk Ae. aegypti menggunakan gelas plastik yang berjumlah 24 buah. Pembuatan larutan uji ekstrak daun tomat $0,1 \%, 0,3 \%, 0,5 \%, 0,7 \%, 1 \%$, dengan mengambil akuades yang dimasukkan ke dalam gelas ukur, kemudian ditambah ekstrak daun tomat dengan menggunakan mikro pipet. Setelah itu, dilakukan pengadukan menggunakan batang pengaduk sampai mendapatkan larutan stok yang homogen. Masing-masing larutan dengan konsentrasi perlakuan dituangkan ke dalam gelas plastik, masing-masing gelas diisi 25 butir telur Ae. aegypti. Pada setiap perlakuan dilakukan pengulangan sebanyak 4 kali, kemudian dilakukan pengamatan setiap 6 jam sekali sampai jam ke 72 (Astuti dkk, 2011). Pengamatan dilakukan dengan melihat telur yang telah menetas menjadi larva.

Data pengamatan berupa jumlah telur yang tidak menetas dianalisis menggunakan one-way ANOVA, bila ada perbedaan jumlah telur yang tidak menetas antar perlakuan secara bermakna, maka dilanjutkan dengan Uji post-hoc LSD dengan taraf signifikan $a=5 \%$. 
HASIL

Berdasarkan hasil penelitian tentang efektivitas ekstrak daun tomat (S. lycopersicum L.) sebagai ovisida nyamuk Ae. aegypti ternyata menunjukkan bahwa semakin tinggi konsentrasi ekstrak daun tomat $(0,1 \%$,
$0,3 \%, 0,5 \%, 0,7 \%$, dan $1 \%$, ) yang digunakan maka semakin banyak jumlah telur yang tidak menetas (pada pengamatan jam ke 18). Data selengkapnya disajikan dalam bentuk grafik (Gambar 1).

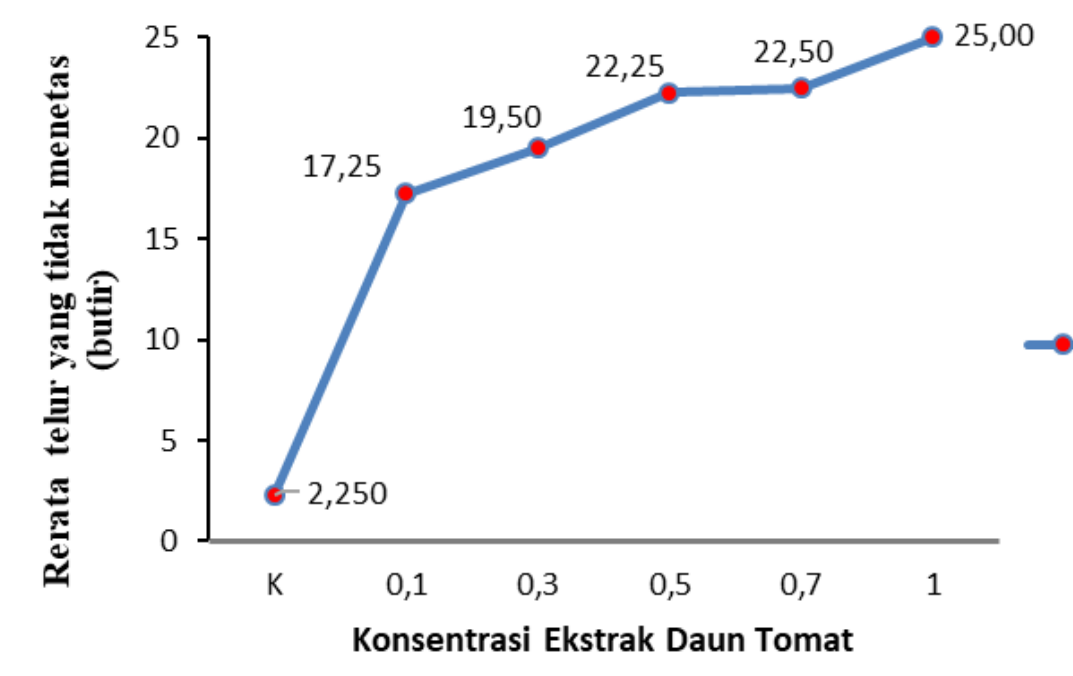

Gambar 1. Grafik Rerata jumlah telur yang tidak menetas pada jam ke 18 dengan berbagai konsentrasi ekstrak daun tomat.

Selanjutnya, data yang berupa jumlah telur yang tidak menetas (jam ke 18) pada berbagai konsentrasi dianalisis dengan one way ANOVA. Hasil analisis menyatakan bahwa terdapat perbedaan rata-rata jumlah telur yang tidak menetas pada setiap perlakuan (konsentrasi ekstrak daun tomat) secara bermakna $(P=0,000)$. Data selengkapnya disajikan pada tabel 1.

Tabel 1. Hasil Analisis One way ANOVA.

\begin{tabular}{cccccc}
\hline \multicolumn{5}{c}{ Telur Yang Tidak Menetas } & \\
\hline & Sum of Squares & df & Mean Square & F & Sig. \\
\hline Between Groups & 1328.000 & 5 & 265.600 & 398.400 & 0.000 \\
Within Groups & 12.000 & 18 & .667 & & \\
Total & 1340.000 & 23 & & \\
\hline
\end{tabular}

Tabel 1 menunjukkan bahwa nilai signifikan $(P=0,000)$ sehingga dapat dikatakan bahwa ekstrak daun tomat (S. lycopersicum L.) memiliki pengaruh sebagai ovisida terhadap telur nyamuk Ae. Aegypti, kemudian dilakukan uji lanjut Post hoc LSD (Least Significant Different) untuk melihat 
jumlah telur terbanyak yang tidak menetas pada konsentrasi berapa. Data selengkapnya disajikan pada tabel 2. Berdasarkan hasil dari uji Post hoc LSD pada tabel 2 menunjukkan bahwa konsentrasi $1 \%$ adalah konsentrasi yang paling banyak ditemukan jumlah telur Ae.aegypti yang tidak menetas.

Tabel 2. Hasil Analisis Post Hoc LSD (Least Significant Different)

\begin{tabular}{cccc}
\hline $\begin{array}{c}\text { Konsentrasi } \\
\text { Ekstrak }\end{array}$ & N & $\begin{array}{c}\text { Rata-rata jumlah telur yang } \\
\text { tidak menetas } \pm \text { StDev }\end{array}$ & LSD \\
\hline $\mathrm{K}$ & 4 & $2,250 \pm 0,500$ & $\mathrm{e}$ \\
$0,1 \%$ & 4 & $17,25 \pm 0,500$ & $\mathrm{~d}$ \\
$0,3 \%$ & 4 & $19,50 \pm 1,291$ & $\mathrm{C}$ \\
$0,5 \%$ & 4 & $22,25 \pm 0,957$ & $\mathrm{~b}$ \\
$0,7 \%$ & 4 & $22,50 \pm 0,577$ & $\mathrm{~b}$ \\
$1 \%$ & 4 & $25 \pm 0,00$ & $\mathrm{a}$ \\
\hline
\end{tabular}

Keterangan : Huruf yang sama pada hasil LSD menunjukkan tidak berbeda nyata dan huruf yang berbeda menunjukkan berbeda nyata.

\section{PEMBAHASAN}

Banyaknya telur yang tidak menetas pada konsentrasi ekstrak daun tomat $1 \%$ diduga karena efek ekstrak daun tomat yang mengandung senyawa metabolit sekunder yaitu flavonoid, saponin, alkaloid dan minyak atsiri yang dapat berperan sebagai ovisida terhadap telur nyamuk $A e$. aegypti. Menurut penelitian Cheah dkk (2013), senyawa aktif yang diduga berperan penting pada proses penghambatan daya tetas telur adalah flavonoid. Hal tersebut sesuai dengan pendapat Purwaningsih dkk (2015), bahwa ekstrak yang mengandung flavonoid mampu menghambat pertumbuhan telur nyamuk Ae. Aegypti menjadi larva bahkan merusak tleur sehingga terjadi kerusakan pada cangkang telur.

$\mathrm{Hal}$ ini juga diperkuat oleh Mayangsari dkk (2015), senyawa lain yang berperan aktif dalam proses penghambatan penetasan telur adalah saponin. Senyawa ini merupakan suatu triterpenoid yang berperan sebagai ecdyson blocker dan merupakan suatu entomotoxicity yang dapat menghambat perkembangan telur menjadi larva. Mekanisme kerja Flavonoid terhadap telur Ae.aegypti menurut Cania dkk (2013), yaitu diduga terjadi karena masuknya zat aktif ke dalam telur melalui titik-titik poligonal yang terdapat pada seluruh permukaan telur. Masuknya zat aktif tersebut dikarenakan potensial insektisida dalam air yang berada dilingkungan luar telur lebih tinggi (hipertonis) dari potensial air yang terdapat di dalam telur (hipotonis) sehingga dapat mengganggu proses metabolisme dan menyebabkan berbagai macam pengaruh terhadap telur.

Mekanisme kerja saponin terhadap telur Ae.aegypti menurut Sudrajat dkk (2010), yaitu diduga terjadi karena kerusakan struktur dinding telur akibat saponin diperburuk dengan adanya minyak atsiri yang mengandung sitronela, yang menyebabkan perubahan permeabilitas pada dinding sel dan mengakibatkan cairan di dalam sel keluar dan berujung pada dehidrasi sel. Dehidrasi sel yang terjadi akan mengakibatkan telur gagal menetas, karena dalam perkembangannya telur memerlukan cairan yang berisi nutrisi. Ekstrak daun tomat memiliki kandungan senyawa saponin, yang merupakan senyawa polar yang dapat berikatan dengan aglikon pada flavonoid sehingga dapat 
menghambat penetasan telur $A e$. aegypti Kendran dkk (2013).

Penelitian ini selaras dengan penelitian Al-Habibi (2013), menggunakan ekstrak daun Legundi sebagai ovisida Ae. aegypti dengan konsentrasi yang sama $0,1 \%, 0,3 \%$, $0,5 \%, 0,7 \%$, dan $1 \%$ menunjukkan hasil bahwa semakin tinggi konsentrasi ekstrak yang digunakan maka semakin tinggi pula daya hambat pada penetasan telur. Dengan demikian telur yang gagal menetas juga akan semakin banyak. Hal ini diduga akibat kesamaan senyawa aktif yang terdapat pada ekstrak daun Legundi (Vitex trifolia L.) dan ekstrak daun Tomat (S. lycopersicum L.) yaitu alkaloid, saponin, flavonoid, dan minyak atsiri.

Selain itu kemampuan menetas telur Ae. aegypti dipengaruhi oleh beberapa faktor lingkungan seperti suhu, $\mathrm{pH}$, intensitas cahaya, kandungan oksigen dan kelembaban. Menurut Yulidar (2014), kisaran suhu optimum untuk perkembangan telur nyamuk adalah $27-30^{\circ} \mathrm{C}$ sedangkan $\mathrm{pH}$ optimum yang dibutuhkan oleh telur nyamuk untuk perkembangannya adalah 6-8 serta oksigen terlarut yang dibutuhkan adalah sebesar $7,9 \mathrm{mg} / \mathrm{l}$ (Arufillah dkk, 2016).

Pada penelitian Sari (2018), menggunakan ekstrak daun kemangi (Ocimum sanctum L.) sebagai ovisida terhadap nyamuk Ae. aegypti dilakukan pengukuran suhu dan $\mathrm{pH}$ air pada tiap konsentrasi perlakuan, dan didapatkan hasil suhu media kisaran $27-28^{\circ} \mathrm{C}$ yang mengindikasi bahwa suhu tidak mempengaruhi zat aktif pada ekstrak daun kemangi, dimana suhu optimum untuk perkembangan telur nyamuk adalah $27-30^{\circ} \mathrm{C}$. Pada penelitian ini juga dilakukan pengukuran $\mathrm{pH}$ dan didapatkan hasil bahwa semakin tinggi konsentrasi ekstrak daun kemangi yang digunakan maka $\mathrm{pH}$ semakin rendah dan kadar oksigen yang terlarut juga semakin rendah sehingga dapat mempengaruhi daya tetas telur nyamuk Ae. aegypti.

Hal ini didukung oleh penelitian Yusrina dkk (2009), bahwa semakin tinggi konsentrasi air rebusan serai yang digunakan maka $\mathrm{pH}$ semakin rendah dan kadar oksigen yang terlarut juga semakin rendah. Keadaan seperti itulah yang diduga dapat mempengaruhi daya tetas telur nyamuk Ae. aegypti. Pada penelitian ekstrak daun tomat diduga rendahnya daya tetas telur nyamuk Ae. aegypti pada konsentrasi $1 \%$ selain dipengaruhi oleh ekstrak daun tomat juga dipengaruhi oleh rendah nya $\mathrm{pH}$ sehingga mempengaruhi kadar oksigen yang semakin rendah.

\section{KESIMPULAN}

Berdasarkan hasil penelitian dan pembahasan, maka dapat disimpulkan bahwa ekstrak daun tomat ( $S$. lycopersicum L.) efektif sebagai ovisida nyamuk Aedes aegypti. dan konsentrasi ekstrak daun tomat (S. lycopersicum L.) yang paling efektif sebagai ovisida nyamuk Aedes aegypti adalah konsentrasi $1 \%$.

\section{SARAN}

Saran dari penelitian yang telah dilakukan yaitu perlu dilakukan penelitian lebih lanjut mengenai uji fitokimia senyawa-senyawa yang terkandung pada daun tomat (S. lycopersicum L.) dan dilakukan penelitian lebih lanjut mengenai senyawa-senyawa yang terkandung pada bagian-bagian tumbuhan tomat lainnya seperti bunga, batang, akar, dan buah yang semuanya nanti diharapkan berfungsi sebagai ovisida alami.

\section{DAFTAR PUSTAKA}

Al-Habibi, F. (2013). Efektivitas Ekstrak Daun Legundi (Vitex negundo) Sebagai Ovisida Aedes aegypti. Skripsi. Fakultas Kedoteran Universitas Lampung.

Anushka, Dishani, U dan Dhivya, R. (2017). Prelimenary Phytochemical Profiling and Ovicidal Potentional of Carica Papaya Leaf Extract Aginst Culex quinquefasciatus. International Journal of Mosquito Research. 4 (3), 34-37. 
Arufillah, M. R., Ismawati, I., dan Kharisma Y. (2016). The Influenza of PH solution Air Tawas Against Power Tetas Eggs Aedes aegypti.S

Astuti, EP., Riyadhi, A., Ahmadi NR. (2011). Efektivitas Minyak Jarak Pagar sebagai Larvasida, AntiOviposisi dan Ovisida Terhadap Larva Nyamuk Aedes albopictus. Bul. Littro. 22 (1) 44-53.

Bria, Rohan, Y. dan Hartini, E. (2008). Pengaruh Konsentrasi Tawas Pada Air Sumur Terhadap Daya Tetas Telur Nyamuk Aedes aegypti di Laboratorium. Jurnal Vektor dan Reservoir Penyakit. 2 (1), 19-21.

Campbell. (2008). Biologi, Edisi Kedelapan Jilid 3. Erlangga. Jakarta.

Cania, BE. dan Setyaningrum, E. (2013). Uji Efektivitas Larvasida Ekstrak Daun Legundi (Vitex trifolia) terhadap Larva Aedes aegypti. Medical Journal of Lampung University, 52(4), 5260.

Cheah, S.-X., Tay, J.-W., Chan, L.-K., dan Jaal, Z. (2013). Larvicidal, oviposition, and ovicidal effects of Artemisia annua (Asteralis: Asteraceae) against Aedes aegypti, Anopheles sinensis, and Culex quinquefasciatus (Diptera: Culicidae). Parasitology Research, 112(9), 3275-3282.

Kendran, A.A.S., Gelgel, Pertiwi, Anthara, Dharmayuda, Anggreni, L.D. (2013). Toksisitas Ekstrak Daun Sirih Merah pada Tikus Putih Penderita Diabetes Melitus, Jurnal Veteriner, 14(4), 527-533.

Mayangsari, I., Sidharti, L., dan Kurniawan, B. (2015). The Effects Of Krisan Flower (Crhysanthemum morifollium) Extract As Ovicide Of Aedes aegypti's Egg. Jurnal Majority, 4(5).

Mitarlis, M. Ismono, I. dan Tukiran, T. (2011). Pengembangan Metode Sintesis Furfural Berbahan Dasar Campuran Limbah Pertanian Dalam Rangka Mewujudkan Prinsip Green Chemistry
(Development of Sinthesis Method Of Furfural Fro Compost Heap Mixture To Reach Out Green Cemistry Principles). Jurnal Manusia dan Lingkungan.18 (3), 191-199.

Purwaningsih, N. V., Kardiwinata, M. P., dan Utami, N. W. A. (2015). Daya Bunuh Ekstrak Daun Srikaya (A. squamosa L.) terhadap Telur dan Larva Aedes aegypti. CAKRA KIMIA (Indonesian E-journal of Applied Chemistry), 3(3), 96-102.

Raveen, R., Ahmed, F., Pandeswari, M., Reegan, D., Tennyson, S., Arivoli, S., dan Jayakumar, M. (2017). Laboratory evaluation of a few plant extracts for their ovicidal, larvicidal and pupicidal activity aginst medically important human dengue, chikungunya and zika virus vector, Ae. Aegypti Linnaeus 1762 (Diptera: Culicidae). Int $J$ Mosq Res, 4(4), 17-28.

Sari, A. N. (2018). Efektivitas ekstrak daun kemangi (Ocimum sanctum L.) sebagai ovisida terhadap nyamuk Ae. aegypti. Skripsi. Universitas Islam Negeri Raden Intan Lampung.

Subashini, K. Sivakkami, R. Jeyansankar, A. (2017). Phytochemical Screening and Ovicidal Activity of Scutellaria Violacea Leaf Extract Against Vector Mosquitoes (Diptera Culicidae). International Journal of Advanced Research Biological Sciences. 4 (3), 523-528.

Sudrajat, Susanto, DA., dan Rahmat. (2010). Daya Racun Ekstrak Daun Sirih Hutan (Piper aduncum LINN) terhadap Larva Nyamuk Aedes aegypti L. Bioprospek. 7(1), 9094.

Sukohar, A. (2014). Demam Berdarah Dengue, Jurnal Kedokteran Universitas Lampung. 2 (2), 2324.

WHO. (2005). Guidelines for Laboratory and Field Testing of Mosquito Larvacides.

Yulidar, L. (2014). Figurative Language Used In Owl City's Albums: A 
Pragmatics

Perspective.

Universitas

Muhammadiyah

Surakarta.

Yusrina U., Gafur A. Pujawati E.D. (2009). Penetasan Telur dan Mortalitas Pupa Nyamuk Aedes aegypti pada Perbedaan Konsentrasi Air Rebusan Serai

(Andropogon nardus L.)

BIOSCIENTIAE. 6(2) 37-48. 